\title{
Efektivitas Repelan Losion Minyak Atsiri Daun Zodia (Evodia Suaveolens) Terhadap Nyamuk Aedes aegypti Linnaeus
}

\author{
Aprilita Rina Yanti Eff *, Ratih Dyah Lestari Ayu Pertiwi, Tyas Putri Utami \\ Program Studi Farmasi Universitas Esa Unggul, Jakarta Barat 11510 \\ *Email korespondensi: aprilita.rinayanti@esaunggul.ac.id
}

(Submit 15/03/2019, Revisi 05/09/2019, Diterima 20/12/2019)

\begin{abstract}
Abstrak
Zodia (Evodia suaveolens) merupakan salah satu tanaman yang mempunyai aroma yang tajam pada bagian bunga dan daunnya dan dipercaya dapat mengusir nyamuk. Daun Zodia mengandung minyak atsiri evodiamine dan rutaecarpine yang tidak disukai oleh nyamuk. Tujuan penelitian ini untuk menilai efektivitas repelen losion mengandung minyak atsiri daun Zodia pada konsentrasi $1 \%, 1.5 \%$ dan $2 \%$. Metodenya dengan iosion yang dibuat dengan mencampurkan minyak atsiri hasil isolasi dari daun Zodia pada konsentrasi $1 \%, 1,5 \%$ dan $2 \%$ ke dalam formulasi sediaan losion yang terdiri dari asam stearat, setil alkohol, parafin cair, dimetikon, vaselin kuning, trietanolamin dan asam sitrat. Pengujian dilakukan dengan cara memasukkan lengan secara bergantian antara lengan yang diberi perlakuan (losion) dan kontrol (tidak diberi perlakuan) ke dalam kurungan nyamuk yang berisi 25 ekor nyamuk Aedes aegypti, kemudian dihitung jumlah nyamuk yang hinggap setiap jam selama enam jam. Efikasi repelan ditentukan berdasarkan daya proteksi yang dihitung dengan rumus : Daya proteksi (DP) $=(\mathrm{K}$ $\mathrm{R}) / \mathrm{K} \times 100 \% ; \mathrm{K}=$ banyaknya hinggapan pada lengan control; $\mathrm{R}=$ banyaknya hinggapan pada lengan pelakuan. Hasil penelitian losion mengandung minyak atsiri daun zodia pada konsentrasi $1 \%, 1,5 \%$ dan $2 \%$ berpotensi sebagai pengusir nyamuk (repelan) Aedes aegypti dengan daya proteksi rata-rata selama enam jam berturut-turut adalah sebesar $74,50 \%, 75,39 \%$ dan $82,45 \%$. Tidak terdapat perbedaan yang signifikan pada daya proteksi antara ke 3 konsentrasi losion ( $>0.05)$ Losion mengandung minyak atsiri daun zodiac pada konsetrasi $1 \%, 1,5 \%$ dan $2 \%$ memiliki efektivitas sebagai repelen. Daya proteksi tertinggi ditunjukkan oleh losion yang mengandung minyak atsiri daun Zodia $2 \%$ yaitu sebesar $82.45 \%$.
\end{abstract}

Kata kunci: Repelen, daun Zodia (Evodia Suaveolens), Aedes aegypty, daya proteksi

\section{Outline}

- Pendahuluan

- Metode

- Hasil dan Pembahasan

- Kesimpulan

- Daftar Pustaka 


\section{Pendahuluan}

Penyakit Demam Berdarah Dengue (DBD) merupakan suatu penyakit yang bisa mengancam jiwa dan menyebabkan kematian. Penyakit ini disebabkan oleh virus dengue dengan nyamuk Aedes aegpty sebagai vektor atau perantaranya. Infeksi virus yang ditularkan oleh nyamuk ini meningkat 30 kali lipat dalam 50 tahun terakhir terutama di negara dengan daerah tropis. Setiap tahun 400 juta orang di dunia terinfeksi penyakit DBD ${ }^{1}$. Nyamuk Aedes aegpty merupakan vektor utama dan Aedes albopictus merupakan vektor pendamping. Kedua spesies nyamuk itu ditemukan di seluruh wilayah Indonesia, hidup optimal pada ketinggian di atas 1000 di atas permukaan laut ${ }^{2}$.

Penyakit demam berdarah di Indonesia masih merupakan masalah kesehatan yang penting. Infeksi terjadi secara endemis dengan manifestasi klinik yang semakin berat. Infeksi dengue di Indonesia telah berubah yang ditandai dengan meningkatnya jumlah kasus di seluruh provinsi di Indonesia dengan pola siklik infeksi ireguler berlatar belakang endemic. Faktor lingkungan, faktor biologi dan demografi mempengaruhi epidemiologi dengue. Cuaca yang hangat dan kelembaban adalah faktor penting dalam insiden dengue, karena perkembangbiakan vektor dan perilaku nyamuk menggigit dapat dirangsang oleh suhu yang tinggi ${ }^{3}$.

Banyak cara yang dilakukan untuk mencegah gigitan nyamuk Aedes aegypti yaitu dengan cara fogging dan penggunaan repelen. Penggunaan fogging dapat menurunkan Insiden Rate (IR) hingga menjadi 3 kasus sedangkan penggunaan repelen pada setiap kelompok perlakuan sangat efektif dalam pencegahan infeksi dan menurunkan IR hingga 4 kasus. Hasil yang paling efektif dalam penurunan IR hingga $0 \%$ didapatkan pada kombinasi antara fogging dengan penggunaan repelen ${ }^{4}$.

Repelan merupakan zat yang berfungsi menghalau, mengusir dan mencegah gigitan nyamuk. Kebanyakan repelen yang beredar di pasaran menggunakan bahan aktif senyawa sintetis. Walaupun aman dan berdaya guna, kelalaian penggunaan senyawa sintetis tersebut dapat membawa implikasi buruk bagi pengguna dan lingkungan. Salah satu senyawa aktif sintetis yang umum digunakan pada repelen tipe oles adalah $\mathrm{N}, \mathrm{N}$ dietil-3-metilbenzamina (DEET). Senyawa tersebut dilaporkan dapat menyebabkan kejang pada anak-anak maupun orang dewasa apabila pemakaiannya tidak tepat, selain itu juga dapat menyebabkan iritasi dan gangguan kulit 5 .

Untuk dapat menghindari efek negatif dari penggunaan antinyamuk yang berasal dari bahan-bahan kimia perlu dilakukan penelitian terhadap antinyamuk yang berasal dari bahan alam (tanaman). Zodia (Evodia suaveolens) termasuk ke dalam keluarga rutaceae merupakan salah satu tanaman yang mempunyai aroma yang tajam pada bagian bunga dan daunnya ${ }^{6}$. Di Indonesia tanaman zodia dipercaya dapat mengusir nyamuk dikarenakan aroma yang menyengat yang dikeluarkannya. Hal tersebut diduga merupakan efek dari bahan aktif yang terkandung dalam minyak atsiri zodia yaitu evodiamine dan rutaecarpine yang tidak disukai oleh nyamuk. Zodia juga mengandung linalool $(46 \%)$ dan $\alpha$-pinene $(13,26 \%)^{7}$, dimana linalool sudah sangat dikenal sebagai pengusir (repelan) nyamuk ${ }^{8}$.

Penelitian ini bertujuan untuk menilai efektivitas losion repelen pada konsentrasi $1 \%, 1.5 \%$ dan $2 \%$. Dari hasil minyak atsiri daun sebagai penelitian ini diperoleh data 
ilmiah mengenai penggunaan losion minyak atsiri daun zodia sebagai repelen dengan menggunakan metode berdasarkan standar pengujian efikasi pestisida yang dikeluarkan oleh Komisi Pestisida Departemen Pertanian?.

\section{Metode}

\section{A. Bahan}

Minyak atsiri hasil isolasi dari daun zodia diperoleh dari Balai Tanaman Rempah dan Obat, stearil alcohol, setil alcohol, paraffin, TEA, dimetikon, vaselin, asam sitrat diperoleh dari Brataco. Telur nyamuk Aedes aegypti betina yang berumur 3-5 hari diperoleh dari Fakultas Kedokteran Hewan IPB..

\section{B. Metode}

1. Pembuatan sediaan losion

Losion minyak atsiri daun Zodia dibuat pada 3 konsentrasi yaitu 1\%, 1.5\% dan 2\% dengan formula seperti terlihat pada tabel $1^{10}$.

Tabel 1. Formula losion

\begin{tabular}{|c|c|c|c|c|}
\hline \multirow{2}{*}{ Formula } & \multicolumn{5}{|c|}{ Bobot \% } \\
\hline Minyak Zodia & I & II & III & IV \\
\hline Parafin cair & 1,5 & 1 & 1,5 & 2 \\
\hline Asam stearat & 3,0 & 1,5 & 1,5 & 1,5 \\
\hline Setil alkohol & 1,0 & 3,0 & 3,0 & 3,0 \\
\hline Dimetikon & 3,0 & 3,0 & 1,0 & 1,0 \\
\hline Vaselin kuning & 1,0 & 1,0 & 3,0 & 3,0 \\
\hline Trietanolamin & 1,5 & 1,5 & 1,0 & 1,0 \\
\hline Air suling & Ad 100 & Ad 100 & Ad 100 & Ad 100 \\
\hline
\end{tabular}

2. Pengembangan dan Pemeliharaan Nyamuk

Telur nyamuk Aedes aegypti strain Liverpool generasi 80 yang akan ditetaskan dimasukkan ke dalam nampan plastik berukuran $30 \times 20 \times 5 \mathrm{~cm} 3$ yang berisi air bersih. Larva yang telah menjadi pupa dipisahkan, pupa diambil dengan menggunakan pipet, kemudian dimasukkan ke dalam gelas plastik berisi air bersih. Nyamuk yang baru menetas diberi air gula dengan perbandingan 1:10. Nyamuk yang digunakan untuk penelitian adalah nyamuk betina berumur 3-5 hari yang sebelumnya telah dipuasakan (tidak diberi pakan gula maupun darah) ${ }^{11}$.

\section{Pengujian aktivitas repelen}

Uji aktivitas repelen dilakukan terhadap 3 orang relawan sehat yang berusia 19-24 tahun pria atau wanita dan tidak memiliki riwayat alergi dan telah mendapatkan persetujuan dari Komisi Etik UEU. Pengujian dilakukan selama 3 hari yaitu hari pertama, kedua dan ketiga. Pengujian dilakukan dengan cara memasukkan lengan secara bergantian antara lengan yang diberi perlakuan (losion) dan kontrol (tidak diberi perlakuan) ke dalam kurungan nyamuk yang berisi 25 ekor nyamuk Aedes aegypti. Banyaknya nyamuk yang hinggap pada tiap lengan diamati mulai dari jam ke 0 (segera setelah pengolesan) sampai jam ke 6 . Tiap konsentrasi losion dilakukan pengulangan sebanyak lima kali. 
Efikasi repelan yang diuji ditentukan berdasarkan daya proteksi yang dihitung dengan rumus :

Daya proteksi $(\mathrm{DP})=\frac{(K-R)}{K} \times 100 \%$

Di mana $\mathrm{K}=$ banyaknya hinggapan padalengan kontrol; $\mathrm{R}=$ banyaknya hinggapan pada lengan pelakuan. Daya proteksi dikatakan efektif bila perlindungan yang diberikan mencapai $90 \%$ sampai dengan jam ke enam. Data yang diperoleh dilakukan uji statistik menggunakan uji Anova taraf kepercayaan $p=0,05^{9}$.

\section{Hasil dan Pembahasan}

Hasil uji aktivitas repelen losion minyak zodia selama enam jam (dalam persen) dapat dilihat pada tabel 2.

Tabel 2. Hasil uji aktivitas repelen losion minyak zodia selama enam jam (\%)

\begin{tabular}{|c|c|c|c|c|c|c|c|c|}
\hline $\begin{array}{c}\text { Konsentrasi } \\
(\%)\end{array}$ & \multicolumn{9}{|c|}{ Jam ke } \\
\hline 1 & 0 & 1 & 2 & 3 & 4 & 5 & 6 & Rata-rata \\
\hline 1,5 & 93,68 & 80,7 & 76,8 & 73,79 & 70,94 & 64,9 & 60,7 & 74,50 \\
\hline 2 & 97,22 & 81,09 & 76,09 & 72,41 & 69,62 & 70,52 & 61,79 & 75,39 \\
\hline & 90,07 & 82,77 & 80,42 & 82,25 & 74,61 & 69,15 & 82,45 \\
\hline
\end{tabular}

Daun zodia yang digunakan dalam penelitian adalah daun yang mengalami pertumbuhan maksimal atau tua karena salah satu faktor yang mempengaruhi produksi minyak atsiri baik sifat dan komposisi hasil tanaman adalah tingkat kemasakan dari daun tersebut. Selain dari faktor luar yang mempengaruhi produksi minyak atsiri adalah faktor dalam. Faktor ini merupakan sifat yang diwariskan induk tanaman seperti bau, rasa, komposisi kimia dan kemampuan produksi biomassa ${ }^{12}$.

Komponen utama minyak atsiri adalah terpenoid yang biasanya terdapat pada fraksi atsiri yang tersuling-uap. Terpenoid inilah penyebab wangi, harum, atau bau yang khas pada daun zodia. Minyak atsiri mempunyai sifat-sifat yaitu tersusun dari bermacammacam komponen senyawa, memiliki bau yang khas rasa yang khas atau getir, sangat mudah larut dalam pelarut organik dan bersifat tidak stabil terhadap pengaruh lingkungan baik pengaruh oksigen udara, sinar matahari dan panas karena terdiri dari berbagai komponen penyususun ${ }^{13}$.

Losion merupakan emulsi cair .yang dimaksudkan untuk pemakaian topikal pada kulit. Losion dapat dibuat sebagai emulsi M/A atau A/M. Emulsi yang dipilih adalah tipe M/A karena mudah dicuci dengan air dan tidak lengket atau berlemak pada kulit ${ }^{6}$.

Nyamuk yang digunakan dalam penelitian adalah nyamuk betina yang berumur 3-5 hari setelah pupa berubah menjadi nyamuk. Nyamuk yang digunakan pada penelitian ini adalah nyamuk betina karena nyamuk betina setelah dewasa akan memerlukan darah sebagai sumber nutrisi bagi perkembangan telur dalam tubuh nyamuk, sedangkan nyamuk jantan hanya menghisap nektar bunga sebagai sumber makanannya. Nyamuk 
dipuasakan pada saat pengujian diharapkan nyamuk dapat lebih aktif mencari darah manusia sebagai sumber makanannya, sehingga dapat terlihat efektifitas daya proteksi repelan zodia ${ }^{11}$.

Dari Tabel 2 terlihat bahwa losion minyak atsiri daun zodia memiliki daya proteksi selama enam jam. Hasil uji statistik pada tiap konsentrasi menunjukkan ada perbedaan yang bermakna dibandingkan kontrol, dan tidak ada perbedaan bermakna antara losion konsenterasi $1 \%, 1,5 \%$ dan $2 \%$. Rata-rata daya proteksi yang dihasilkan berturut-turut sampai jam keenam setelah pengolesan adalah $74,50 \%, 75,39 \%$ dan $82,45 \%$. Setiap konsentrasi dapat memberikan perlindungan yang sangat baik terhadap hinggapan dan gigitan nyamuk Aedes aegypti. Secara keseluruhan semakin tinggi konsentrasi rminyak atsiri pada losion menunjukan kencenderungan proteksi terhadap gigitan nyamuk yang semakin baik. Konsentrasi suatu bahan aktif sangat berpengaruh terhadap efektivitas suatu sediaan penolak nyamuk, dimana semakin besar konsentrasi bahan aktif maka efek repelan atau penolak nyamuk juga semakin besar dan daya efektivitasnya juga semakin lama. Daun zodia mengandung evodiamine, rutacerpine, linalool dan a-pinen yang berfungsi sebagai penolak nyamuk. Secara keseluruhan semakin tinggi konsentrasi repelan menunjukan kencenderungan proteksi terhadap gigitan nyamuk yang semakin baik.

Hal yang mempengaruhi kerja repelan terhadap nyamuk yaitu menghambat respon terhadap sinyal lain yang menarik, mengganti pesan sensorik nyamuk menjadi daya tarik tolakan, mengaktifkan sistem reseptor yang mengendalikan perilaku yang bersaing, mengaktifkan reseptor bau beracun, mengaktifkan jenis reseptor yang berbeda secara bersamaan sehingga menyebabkan hilangnya sinyal khusus untuk menemukan host ${ }^{14}$.

Menurut komisi pestisida daya proteksi dikatakan efektif bila mencapai angka $90 \%$, namun standar ini ditetapkan untuk repelan dengan bahan kimia sintetik. Bahan kimia sintetik yang umumnya digunakan adalah bahan aktif N,N-dietil-3-metilbenzamina (DEET). Berbeda halnya dengan repelan yang berasal dari tanaman, hingga saat ini belum ditetapkan nilai standar yang menjadi kriteria baik tidaknya suatu repelan.

\section{Kesimpulan}

Losion minyak atsiri daun zodiac (Evodia Suaveolens) pada konsentrasi 1,1.5\% dan 2\% memiliki aktivitas dan efektif sebagai repelen terhadap nyamuk Aedes aegypti Linnaeus.

\section{Daftar Pustaka}

1. Sanyaolu A, Okorie C, Badaru O, Adetona K, Ahmed M, Akanbi O. Global Epidemiology of Dengue Hemorrhagic Fever : An Update. J Hum Virol Retrovirology. 2017;5(6):1-7.

2. Candra A. Demam Berdarah Dengue: Epidemiologi, Patogenesis dan Faktor Risiko Penularan Dengue Hemorrhagic. Aspirator. 2010;2(2):110-9.

3. Karyanti MR. Perubahan Epidemiologi Demam Berdarah Dengue Di Indonesia. Sari Pediatr. 2009;10(6):424-32. 
4. Perwitasari D, Munif A, Supriatna Aa. Model Intervensi Pengendalian Demam Berdarah Dengue (DBD) Untuk Menurunkan Insident Rate (IR) Berdasarkan Kombinasi Fogging Dan Repelen Di Kabupaten Sintang Propinsi Kalimantan Barat Tahun 2011. J Ekol Kesehat. 2013;12(1):57-71.

5. Garud A, Ganesan K, Garud N, Vijayaraghavan R. Topical Preparation of Newer and Safer Analogs of N, N-Diethyl-2-phenylacetamide (DEPA) against Aedes aegypti Mosquitoes. J Cosmet Dermatological Sci Appl. 2013;3(January):22-7.

6. Datta S, A Ghosh, S Sarkar, P Deka, T Choudhuri, P Par dan PK Kar. Herbal Mosquito Repellens. Int J of Pharm Sci and Biotechnology. 2010; 1(4): 195-202.

7. Maryuni, A.E. Isolasi dan Identifikasi Senyawa Antibakteri Minyak Atsiri Daun Zodia. Sekolah Pascasarjana Institut Pertanian Bogor. 2008

8. Gozali D, Ida M, Mutakin, Kartika A. Uji Aktivitas Antinyamuk dari Ekstrak Daun Zodia (Evodia suaveolens Scheff) Terhadap Nyamuk Culex fatigan dalam Sediaan Cream. Farmaka. 2009,7(3): 1-14.

9. Komisi Pestisida Departemen Pertanian. Metode Standart Pengujian Efikasi Pestisida. Departemen Pertanian. Jakarta. 1999:14-9

10. Agrawal S. Formulation of Natural Mosquito Repellent. Int J Adv Res Ideas Innov Technol. 2018;4(1):11-7.

11. Setiyaningsih $\mathrm{R}$, Alfiah $\mathrm{S}$. Pengaruh Suhu Penyimpanan Terhadap Presentase Tetas Telur. Vektora. 2014;6(1):9-12.

12. Pratiwi A, Utami LB. Isolasi dan Analisis Kandungan Minyak Atsiri pada Kembang Leson. Bioeksperimen. 2018;4(1):42-7.

13. Bhargava V, Patel S, Desai K. Importance of Terpenoids and Essential Oils in Chemotaxonomic Approach Vidita. Int J Herb Med Importance. 2013;1(2):14-21.

14. Dickens JC, Bohbot JD. Mini review : Mode of action of mosquito repellents. Pestic Biochem Physiol. 2013;02:1-7. 